\title{
ANALISIS FAKTOR-FAKTOR YANG MEMPENGARUHI KEPUTUSAN PEMBELIAN KONSUMEN DI PAJAK USU (PAJUS) MEDAN
}

\author{
Dedy Ansari Harahap \\ Dosen FE UISU \\ deanhar@yahoo.com
}

\begin{abstract}
Abstrak
This research aimed to analyzed the factors that influence consumer purchase decisions in Pajak USU (Pajus) Medan ie location, completeness of the product and prices. Samples were taken totaling 96 respondents. Data collection techniques that used were questionnaire using a Likert Scale measurement and statistical processing with multiple linear regression method.

After analyzing the data, this research obtained that the location, completeness of the product and price influenced purchasing decisions amounted to 0.718 (71.80\%), which meant that the location, the completeness of the product and the price had a contribution and influenced the purchasing decisions of consumers by $71.80 \%$, while $28.2 \%$ influenced by other factors. To test the hypothesis in this research $t$ test showed that the research hypothesis for X2 and X3 accepted, meant that there were positive and significant influences between variable range of products and prices on consumer purchasing decisions in Pajak USU (Pajus) Medan. While the research hypothesis for XI was rejected, meant that there was no positive and significant influence between variable locations on consumer purchasing decisions in Pajak USU (Pajus) Medan. From statistical F test, obtained that simultaneously, location, completeness of the product and prices influenced consumer purchasing decisions significantly.
\end{abstract}

Keywords : Location, Price, Completeness of the Product, Purchasing Decisions

\section{PENDAHULUAN}

Seiring dengan peningkatan pengetahuan, konsumen semakin lebih tahu cara membelanjakan uangnya. Konsumen dapat membeli produk yang mereka butuhkan sesuai dengan jumlah yang diinginkan. Konsumen dapat menyesuaikan pembelian produk dengan uang yang mereka miliki karena konsumen semakin mengetahui prioritas kebutuhan mereka akan produk tertentu.

Jadi, konsumen merupakan faktor penting bagi perusahaan. Perusahaan harus benar-benar memfokuskan perhatian kepada konsumen karena dalam persaingan yang begitu sengit dewasa ini, konsumen tidak saja mendapat tawaran produk dari satu perusahaan, tetapi juga dari berbagai perusahaan pesaing lainnya yang menawarkan produk sejenis. Perusahaan harus memiliki strategi menarik yang berbeda dengan pesaing agar produknya selalu diminati dan dibeli konsumen.
Bahkan sekarang ini, jumlah penawaran produk lebih besar dibanding jumlah permintaan konsumen. Hal ini yang menunjukkan bahwa produsen tidak bisa lagi hanya berdiam diri tanpa perlu mencari informasi mengenai konsumennya.

Keputusan pembelian adalah tindakan yang dilakukan konsumen untuk melakukan pembelian sebuah produk. Oleh karena itu, pengambilan keputusan pembelian konsumen merupakan suatu proses pemilihan salah satu dari beberapa alternatif penyelesaian masalah dengan tindak lanjut yang nyata. Setelah itu konsumen dapat melakukan evaluasi pilihan dan kemudian dapat menentukan sikap yang akan diambil selanjutnya. Dalam sebuah keputusan pembelian terdapat beberapa peran konsumen yaitu inisiator, influencer, decider, buyer, user. Perusahaan perlu mengenal peranan tersebut karena semua peranan mengandung implikasi guna merancang 
produk, menentukan pesan dan mengalokasikan biaya anggaran promosi serta membuat program pemasaran yang sesuai dengan pembeli (Swastha dan Handoko, 2011). Terdapat empat faktor yang mempengaruhi perilaku keputusan pembelian konsumen yaitu budaya, sosial, pribadi dan psikologis (Kotler, 2003:202).

Adapun yang menjadi faktor-faktor keputusan pembelian yang dipertimbangkan peneliti adalah lokasi, kelengkapan produk dan harga. Lokasi merupakan salah satu faktor penentu kesuksesan sebuah usaha karena mempengaruhi biaya usaha. Lokasi usaha harus dipertimbangkan dengan sebaik mungkin. Jika perusahaan salah dalam memilih lokasi, maka perusahaan akan menanggung resiko berupa kerugian atau tidak tercapai sasaran dan tujuan yang diinginkan oleh perusahaan.

Faktor kedua selain lokasi adalah kelengkapan produk. Setiap konsumen menginginkan barang yang lengkap ketika konsumen memasuki satu tempat belanja. Kalau memang ada, konsumen menginginkan satu tempat belanja yang dapat memenuhi kebutuhan dan keinginannya secara sekaligus untuk berbagai jenis barang atau jasa. Konsumen selalu ingin efisien. Oleh karena itu, perusahaan diharapkan memperhatikan lebar dan kedalaman produk, kualitas dan lengkap karena menyediakan produk yang lengkap adalah penting sebab adanya kecendrungan dalam diri konsumen yang menghendaki barang-barang bersifat substitusi dan komplementer, sehingga dengan lengkapnya produk tersebut, konsumen dapat leluasa memilih apa yang menjadi kebutuhannya karena apa yang dibutuhkan konsumen sudah tersedia di satu tempat belanja tersebut.

Faktor lain yang mempengaruhi keputusan pembelian adalah harga. Harga dapat menjadi indikator kualitas produk. Konsumen biasanya mengidentikkan harga produk yang mahal dengan kualitas yang baik dan apabila harga produk murah, maka konsumen meragukan kualitasnya. Ketika seseorang berbelanja, hal awal yang sering diperhatikan adalah harga, disusul dengan beberapa faktor lain. Penetapan harga pada suatu produk haruslah sesuai dan wajar. Tingginya harga yang ditawarkan harus sesuai dengan manfaat yang akan diterima oleh konsumen yang mengkonsumsinya. Harga yang terlalu tinggi atau terlalu rendah akan mempengaruhi keputusan pembelian konsumen. Harga yang terlalu tinggi akan membuat konsumen beralih ke produk lain yang sejenis tetapi dengan harga yang lebih murah, begitu sebaliknya, jika harga yang ditawarkan terlalu rendah maka konsumen akan ragu dengan kualitas produk yang ditawarkan sehingga menunda keputusan untuk membeli produk tersebut.

Pajak USU (Pajus) merupakan salah satu pusat perbelanjaan di kota Medan, tepatnya di daerah kampus USU. Pada awalnya pajak USU (Pajus) merupakan kumpulan beberapa pedagang yang mendirikan tenda- tenda untuk menjual berbagai makanan di bawah kebun kelapa sawit. Kemudian pasca kebakaran yang melanda kawasan ini, Pajak USU (Pajus) dibenahi lebih baik lagi oleh Universitas Sumatera Utara sehingga semakin berkembang sampai saat ini (www.ayogitabisa.com).

Pajak USU (Pajus) sudah dikenal masyarakat Medan dikarenakan menjual berbagai kebutuhan masyarakat terutama mahasiswa dan kalangan muda. Misalnya alat tulis, aksesoris, pakaian, sepatu, gadget dan perlengkapannya, makanan, minuman dan sebagainya. Karena banyaknya barang yang ditawarkan, kebanyakan konsumen mengatakan lebih suka berbelanja di pajak ini dibandingkan di swalayan maupun plaza karena harga yang jauh lebih murah dengan kualitas yang sama. Oleh karena itu konsumen yang berbelanja di Pajak USU (Pajus) bukan hanya dari mahasiswa USU tetapi juga dari perguruan tinggi lain, siswa SLTP, SMU dan masyarakat umum.

Dari uraian di atas maka perlu kiranya Pajak USU (Pajus) memperhatikan lokasi, kelengkapan produk dan harga dalam menentukan keputusan pembelian konsumen sehingga konsumen diharapkan melakukan pembelian ulang di masa akan datang.

\section{Perumusan Masalah}

1. Apakah terdapat pengaruh lokasi terhadap keputusan pembelian konsumen Pajak USU (Pajus) Medan? 
2. Apakah terdapat pengaruh kelengkapan produk terhadap keputusan pembelian konsumen Pajak USU (Pajus) Medan?

3. Apakah terdapat pengaruh harga terhadap keputusan pembelian konsumen Pajak USU (Pajus) Medan?

4. Apakah terdapat pengaruh lokasi, kelengkapan produk dan harga secara bersama-sama terhadap keputusan pembelian konsumen Pajak USU (Pajus) Medan?

\section{KAJIAN PUSTAKA}

\section{Lokasi}

\section{a. Pengertian Lokasi}

Menurut Swastha (2000:187) mengemukakan bahwa "lokasi (place) menunjukkan berbagai kegiatan yang dilakukan perusahaan untuk menjadikan produknya dapat diperoleh dan tersedia bagi konsumen".

Sedangkan menurut Nelson (dalam Rahman, 2013) menyatakan "ada prinsipprinsip yang harus dipertimbangkan dalam memilih lokasi suatu bisnis, yaitu daerah perdagangan yang cukup potensial, tempat mudah dijangkau, mempunyai potensi pertumbuhan, terletak dalam arus bisnis, ada daya tarik yang kuat, dalam lalu lintas lancar persaingan kecil".

Lokasi adalah tempat di mana perusahaan harus bermarkas melakukan operasi (Lupiyoadi, 2001:61). Dalam hal ini ada tiga jenis interaksi yang mempengaruhi lokasi, yaitu:

1. Konsumen mendatangi pemberi jasa (perusahaan), apabila keadaannya seperti ini maka lokasi menjadi sangat penting. Perusahaan sebaiknya memilih tempat dekat dengan konsumen sehingga mudah dijangkau dengan kata lain harus strategis;

2. Pemberi jasa mendatangi konsumen, dalam hal ini lokasi tidak terlalu penting tetapi yang harus diperhatikan adalah penyampaian jasa harus tetap berkualitas;

3. Pemberi jasa dan konsumen tidak bertemu langsung, berarti service provider dan konsumen berinteraksi melalui sarana tertentu seperti telepon, komputer, dan surat.

\section{b. Indikator Lokasi}

Menurut Tjiptono dan Chandra (2001:33), pemilihan lokasi fisik memerlukan pertimbangan cermat terutama faktor-faktor berikut:

1) Akses, yaitu lokasi yang dilalui mudah dijangkau sarana transportasi Umum.

2) Visibilitas, yaitu lokasi atau tempat yang dapat dilihat dengan jelas dari jarak pandang normal.

3) Lalu lintas (traffic) dimana ada dua hal yang perlu dipertimbangkan:

a. Banyak orang yang berlalu lalang bisa memberikan peluang besar terjadinya impulse buying, yaitu keputusan pembelian yang sering terjadi spontan atau tanpa perencanaan

b. Kepadatan dan kemacetan lalu lintas bisa juga menjadi hambatan, misalnya terhadap pelayanan kepolisian, pemadam kebakaran, atau ambulance.

4) Tempat parkir yang luas, nyaman dan aman.

5) Ekspansi, yaitu tersedia tempat yang cukup luas untuk perluasan usaha di kemudian hari.

6) Lingkungan, yaitu daerah sekitar yang mendukung jasa yang ditawarkan.

7) Kompetisi, yaitu lokasi pesaing. Dalam menentukan lokasi sebuah usaha, perlu dipertimbangkan apakah di jalan atau daerah tersebut telah terdapat banyak usaha yang sejenis atau tidak.

8) Peraturan Pemerintah yang berisi ketentuan untuk mengatur lokasi dari sebuah usaha-usaha tertentu, misalnya bengkel kendaraan bermotor dilarang berlokasi yang terlalu berdekatan dengan tempat ibadah.

\section{Kelengkapan Produk}

\section{a. Pengertian Kelengkapan Produk}

Kelengkapan produk merupakan suatu yang dapat ditawarkan kedalam pasar untuk diperhatikan, dimiliki, dipakai, atau dikonsumsi sehingga dapat memenuhi keinginan atau kebutuhan (Kotler dan Armstrong, 2004:345).

Lebih lanjut Kotler (2008:347) dalam penjelasannya menyatakan bahwa "kelengkapan produk adalah tersedianya semua jenis produk yang ditawarkan untuk 
dimilik, dipakai atau dikonsumsi oleh konsumen yang di hasilkan oleh produsen" Menurut Engel (2002:258) kelengkapan produk adalah kelengkapan produk yang menyangkut kedalaman,luas dan kualitas produk yang ditawarkan juga ketersediaan produk tersebut setiap saat di toko.

\section{b. Kelengkapan Produk dan Strategi Pembedaan Produk Bagi Pengecer}

Kelengkapan produk ritel harus dilakukan dengan sangat hati-hati. Ide dan pemikiran tidak hanya difokuskan pada jenis barang namun juga fasilitas pendukung maupun pelayanan yang menyertainya. Utami (2006:167)

Jenis produk pengecer pun harus cocok dengan harapan konsumen, disamping itu pilihan produk menjadi unsur penting dalam ajang persaingan diantara pengecer. Oleh karena itu, pengecer harus menyusun strategi produk yang berbedabeda. Wortzel (dalam Kotler, 2008:15) menyarankan beberapa strategi pembedaan produk bagi para pengecer sebagai berikut :

a. Mengikutsertakan sejumlah merk nasional eksklusif yang tidak dimiliki oleh pengecer pasaing.

b. Sebagaian merek yang dijual bermerek sendiri.

c. Menyelenggarakan peragaan-peragaan produk khas yang sangat terkenal.

d. Mengikutsertakan produk sampingan atau secara terus menerus mangganti sebagian barang-barang yang dijual.

e. Menjadi yang pertama dalam mengikutsertakan produk terbaru.

f. Menawarkan produk yang spesifikasinya disesuaikan dengan keinginan pembeli.

g. Menawarkan bauran dengan sasaran yang sempit.

\section{c. Indikator Kelengkapan Produk}

Raharjani (2005:8), mengemukakan variabel kelengkapan produk meliputi keragaman barang yang dijual di pasar swalayan dan ketersediaan barang-barang tersebut di pasar swalayan. Indikator dari kelengkapan produk, yaitu:

1. Kelengkapan jenis produk yang ditawarkan.
2. Kelengkapan produk merk yang ditawarkan.

3. Kelengkapan produk variasi ukuran yang ditawarkan

4. Kelengkapan produk variasi kualitas produk yang ditawarkan.

\section{Harga}

\section{a. Pengertian Harga}

Menurut Kotler (2009:67) "Harga adalah jumlah uang yang ditukarkan konsumen dengan manfaat dari memiliki atau menggunakan produk dan jasa. Harga berperan sebagai penentu utama pilihan pembeli. Harga merupakan satu-satunya elemen bauran pemasaran yang menghasilkan pendapatan, elemen-elemen lain menimbulkan biaya".

"Harga adalah sejumlah uang yang ditukarkan untuk produk atau jasa, lebih jauh lagi harga adalah jumlah dari seluruh nilai yang konsumen tukarkan untuk jumlah manfaat dengan memiliki atau menggunakan suatu barang dan jasa" (Kotler \& Amstrong 2001:14).

"Harga adalah jumlah uang yang telah disepakati oleh calon pembeli dan penjual untuk ditukar dengan barang atau jasa dalam transaksi bisnis normal" (Tandjung, 2004:78).

\section{b. Tujuan Penetapan Harga}

Menurut Saladin (2006:142), ada 6 (enam) tujuan yang dapat diraih perusahaan melalui penetapan harga, yaitu :

1. Bertahan hidup (survival)

Pada kondisi tertentu (karena adanya kapasitas yang menganggur, persaingan yang semaikin gencar atau perubahan keinginan konsumen, atau mungkin juga kesulitan keuangan), maka perusahaan menetapkan harga jualnya dibawah biaya total produk tersebut atau bibawah harga pasar. Tujuannya adalah bertahan bidup (survival) dalam jangka pendek. Untuk berahan hidup jangka panjang, harus mencari jalan keluar lainnya. 2. Memaksimalkan laba jangka pendek (maximum current profit)

Perusahaan merasa yakin bahwa dengan volume penjualan yang tinggi akan mengakibatkan biaya per unit lebih rendah dan keuntungan yang lebih tinggi. Perusahaan menetapkan harga serendah- 
rendahnya dengan asumsi pasar sangat peka terhadap harga. Ini dinamakan "penentuan harga untuk menerobos pasar (market penetration pricing)". Hal ini hanya dapat dilakukan apabila :

a. Pasar sangat peka terhadap harga, dan rendahnya harga sangat merangsang pertumbuhan pasar.

b. Biaya produksi dari distribusi menurun sejalan dengan bertambahnya produksi.

c. Rendahnya harga akan melemahkan persaingan.

3. Memaksimalkan hasil penjualan (maximum current revenue)

Untuk memaksimalkan hasil penjualan, perusahaan perlu memahami fungsi permintaan. Banyak perusahaan berpendapat bahwa maksimalisasi hasil penjualan itu akan mengantarkan perusahaan memperoleh maksimalisasi laba dalam jangka panjang dan pertumbuhan bagian pasar.

4. Menyaring pasar secara maksimum (maximum market skiming)

Banyak perusahaan menetapkan harga untuk menyaring pasar (market skiming price). Hal ini dilakukan untuk menarik segmen-segmen baru. Mula-mula dimunculkan ke pasar produk baru dengan harga tinggi, beberapa lama kemudian dimunculkan produk baru dengan harga tinggi, beberapa lama kemudian dimunculkan pula produk yang sama dengan harga yang lebih rendah.

5. Menentukan permintaan (determinant demand)

Penetapan harga jual membawa akibat pada jumlah permintaan.

\section{c. Metode Penetapan Harga}

Menurut Tjiptono (2008:152) metode penetapan secara garis besar dikelompokan menjadi empat kategori utama, yaitu metode penetapan harga berbasis permintaan, berbasis biaya, berbasis laba, dan berbasis persaingan.

1. Metode penetapan berbasis permintaan

Metode ini lebih menekankan faktor- faktor yang mempengaruhi selera dan preferensi pelanggan daripada faktor-faktor seperti biaya, laba, dan persaingan.

Permintaan pelanggan sendiri didasarkan pada berbagai pertimbangan, diantaranya yaitu:

a. Kemampuan para pelanggan untuk membeli (daya beli)

b. Kemauan pelanggan untuk membeli

c. Posisi suatu produk dalam gaya hidup pelanggan, yakni menyangkut

d. Apakah produk tersebut merupakan symbol status atau hanya produk

e. Manfaat yang diberikan produk tersebut kepada pelanggan.

f. Harga-harga produk substitusi

2. Metode Penetapan Harga Berbasis Biaya

Dalam metode ini faktor penentu yang utama adalah aspek penawaran atau biaya, bukan aspek permintaan. Harga ditentukan berdasarkan biaya produksi dan pemasaran yang ditambah dengan jumlah tertentu sehingga menutupi biaya-biaya langsung, biaya overhead dan laba.

3. Metode Penetapan Harga Berbasis Laba

Metode ini berusaha menyeimbangkan pendapatan dan biaya dalam penetapan harganya. Upaya ini dilakukan atas dasar target volume laba spesifik atau dinyatakan dalam bentuk persentase terhadap penjualan atau investasi.

4. Metode Penetapan Harga Berbasis persaingan

Selain berdasarkan pada pertimbangan biaya, permintaan, atau laba harga juga dapat ditetapkan atas dasar persaingan, yaitu apa yang dilakukan pesaing. Metode penetapan harga berbasis persaingan terdiri atas empat macam : customary pricing, above, at, or below market pricing, loss leader pricing, sealed bid pricing. 


\section{d. Indikator Harga}

Menurut Kotler dan Armstrong (2008:278), ada empat indikator yang mencirikan harga yaitu:

a. Keterjangkauan harga,

b. Kesesuaian harga dengan kualitas produk,

c. Daya saing harga, dan

d. Kesesuaian harga dengan manfaat.

\section{Keputusan Pembelian}

\section{a. Pengertian Keputusan Pembelian}

Menurut Schiffman, Kanuk (2004:547), keputusan pembelian adalah pemilihan dari dua atau lebih alternatif pilihan keputusan pembelian, artinya bahwa seseorang dapat membuat keputusan, harus tersedia beberapa alternatif pilihan. Keputusan untuk membeli dapat mengarah pada bagaimana proses dalam pengambilan keputusan tersebut itu dilakukan.
Assauri
(dalam
Sahetapy,

2013:141) menyatakan bahwa: "Keputusan pembelian merupakan suatu proses pengambilan keputusan akan pembelian yang mencakup penentuan apa yang akan dibeli atau tidak melakukan pembelian dan keputusan itu diperoleh dari kegiatankegiatan sebelumnya".

Sedangkan menurut Kotler (2005) menyatakan bahwa: "Keputusan pembelian adalah suatu proses penyelesaian masalah yang terdiri dari menganalisa kebutuhan dan keinginan, pencarian informasi, penilaian sumber-sumber seleksi terhadap alternatif pembelian, keputusan pembelian, dan perilaku setelah pembelian."

\section{b.Tahap Proses Keputusan Pembelian}

Dalam mempelajari keputusan pembelian konsumen, seorang pemasar harus melihat hal-hal yang berpengaruh terhadap keputusan pembelian dan membuat suatu ketetapan konsumen membuat keputusan pembeliannya.

Kotler (2002:204) mengemukakan proses pembelian tersebut melalui lima tahapan. Tahapan pembelian konsumen tersebut antara lain adalah:

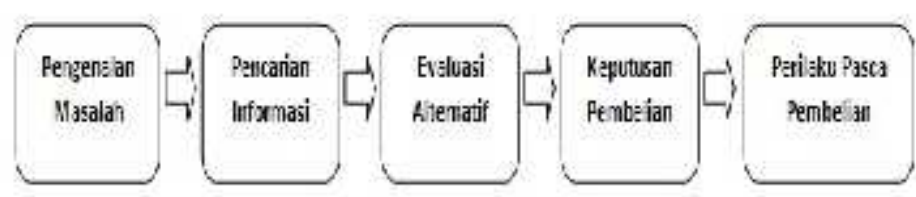

Gambar 1. Proses Pengambila

\section{Keputusan}

1. Pengenalan masalah (problem recognition)

Proses pembelian diawali dengan adanya masalah atau kebutuhan yang dirasakan oleh konsumen. Konsumen mempersepsikan perbedaan antara keadaan yang diinginkan dengan situasi saat ini guna membangkitkan dan mengaktifkan proses keputusan.

2. Pencarian informasi (information search)

Setelah konsumen merasakan adanya kebutuhan suatu barang atau jasa, selanjutnya konsumen mencari informasi baik yang disimpan dalam ingatan (internal) maupun informasi yang didapat dari lingkungan (eksternal).

Sumber-sumber informasi konsumen terdiri dari :

a. Sumber pribadi : keluarga, teman, tetangga, kenalan.

b. Sumber niaga/komersial : iklan, tenaga penjual, kemasan, dan pemajangan

c. Sumber umum : media massa dan organisasi konsumen

d. Sumber pengalaman : penanganan, pemeriksaan, penggunaan produk

3. Evaluasi alternatif (validation of alternativ)

Setelah inforasi di peroleh, konsumen mengevaluasi berbagai alternatif pilihan dalam memenuhi kebutuhan tersebut. Untuk menilai alternatif pilihan konsumen terdapat 5 (lima) konsep dasar yang dapat digunakan, yaitu :

a. Sifat-sifat produk, apa yang menjadi ciri-ciri khusus dan 
perhatian konsumen terhadap produk atau jasa tersebut.

b. Pemasar hendaknya lebih memperhatikan pentingnya ciri-ciri produk dari pada penonjolan ciri-ciri produk.

c. Kepercayaan konsumen terhadap ciri merek yang menonjol.

d. Fungsi kemanfaatan, yaitu bagaimana konsumen mengharapkan kepuasan yang diperoleh dengan tingkat alternatif yang berbeda-beda setiap hari.

e. Bagaimana prosedur penilaian yang dilakukan konsumen dari sekian banyak ciri-ciri barang.

4. Keputusan Pembelian (purchase decision)

Konsumen yang telah melakukan pilihan terhadap berbagai alternatif biasanya membeli produk yang paling disukai, yang membentuk suatu keputusan untuk membeli. Ada 3 (tiga) faktor yang menyebabkan timbulnya keputusan untuk membeli, yaitu :

a. Sikap orang lain : tetangga, teman, orang kepercayaan, keluarga, dll.

b. Situasi tak terduga : harga, pendapatan keluarga, manfaat yang diharapkan
c. Faktor yang dapat diduga : factor situasional yang dapat diantisipasi oleh konsumen

5. Perilaku pasca pembelian (post purchase behavior)

Kepuasan atau ketidak puasan konsumen terhadap suatu produk akan berpengaruh terhadap perilaku pembelian selanjutnya. Jika konsumen puas kemungkinan besar akan melakukan pembelian ulang dan begitu juga sebaliknya. Ketidakpuasan konsumen akan terjadi jika konsumen mengalami pengharapan yang tak terpenuhi. Konsumen yang merasa tidak puas akan menghentikan pembelian produk yang bersangkutan dan kemungkinan akan menyebarkan berita buruk tersebut ke temanteman mereka. Oleh karena itu perusahaan berusaha memastikan tercapainya kepuasan konsumen pada semua tingkat dalam proses pembelian.

\section{c. Indikator Keputusan Pembelian}

Indikator dari keputusan pembelian (dalam Soewito : 2013) :
a) Kebutuhan yang dirasakan
b) Kegiatan sebelum membeli
c) Perilaku waktu memakai
d) Perilaku pasca pembelian 


\section{Penelitian Relevan}

Tabel 1.

Penelitian Relevan

\begin{tabular}{|c|c|c|c|c|}
\hline No. & Penulis & Judul & Hasil & Jurnal \\
\hline 1. & $\begin{array}{l}\text { Fifyanita } \\
\text { Ghanimata dan } \\
\text { Mustafa Kamal } \\
\text { (2012) }\end{array}$ & $\begin{array}{l}\text { Analisis Pengaruh Harga, } \\
\text { Kualitas Produk dan } \\
\text { Lokasi Terhadap } \\
\text { Keputusan Pembelian } \\
\text { (Studi pada Pembeli } \\
\text { Produk Bandeng Juwana } \\
\text { Elrina Semarang) }\end{array}$ & $\begin{array}{l}\text { Ketiga variabel } \\
\text { berpengaruh positif dan } \\
\text { signifikan terhadap } \\
\text { keputusan pembelian. } \\
\text { Lokasi mempunyai } \\
\text { pengaruh yang sangat } \\
\text { besar dibanding harga dan } \\
\text { kualitas produk. }\end{array}$ & $\begin{array}{l}\text { Diponegoro Journal } \\
\text { Of Management. } \\
\text { Vol.1, No. } 2: 1-10\end{array}$ \\
\hline 2. & $\begin{array}{l}\text { Agnes Ligia } \\
\text { Pratisitia } \\
\text { Walukow, } \\
\text { Lisbeth } \\
\text { Mananeke, } \\
\text { Jantje Sepang } \\
\text { (2014) }\end{array}$ & $\begin{array}{l}\text { Pengaruh Kualitas } \\
\text { Produk, Harga, Promosi } \\
\text { Dan Lokasi Terhadap } \\
\text { Keputusan Pembelian } \\
\text { Konsumen Di Bentenan } \\
\text { Center Sonder Minahasa }\end{array}$ & $\begin{array}{l}\text { Ketiga variabel } \\
\text { berpengaruh positif dan } \\
\text { signifikan secara simultan } \\
\text { terhadap keputusan } \\
\text { pembelian konsumen. } \\
\text { Tetapi secara parsial lokasi } \\
\text { tidak berpengaruh. }\end{array}$ & $\begin{array}{l}\text { Jurnal EMBA } \\
\text { Vol.2 No.3 : 1737- } \\
1749\end{array}$ \\
\hline 3. & $\begin{array}{l}\text { Muhammad } \\
\text { Wahyu Ali A. } \\
\text { H, Handoyo } \\
\text { Djoko.W, Sari } \\
\text { Listyorini } \\
\text { (2013) }\end{array}$ & $\begin{array}{l}\text { Pengaruh Keragaman } \\
\text { Menu, Kualitas Produk, } \\
\text { Citra Merek Dan Iklan } \\
\text { Terhadap Keputusan } \\
\text { Pembelian }\end{array}$ & $\begin{array}{l}\text { Ketiga variabel } \\
\text { berpengaruh terhadap } \\
\text { keputusan pembelian. } \\
\text { Keragaman menu } \\
\text { merupakan variabel yang } \\
\text { paling berpengaruh }\end{array}$ & $\begin{array}{l}\text { Diponegoro Journal } \\
\text { Of Social And } \\
\text { Politic, } \\
\text { http://ejournals1.un } \\
\text { dip.ac.id/index.php/ } \\
: 1-9\end{array}$ \\
\hline 4. & $\begin{array}{l}\text { Hendri Sukotjo } \\
\text { dan Sumanto } \\
\text { Radix A (2010) }\end{array}$ & $\begin{array}{l}\text { Analisa } \\
\text { Marketing Mix-7P } \\
\text { (Produk, Price, } \\
\text { Promotion, Place, } \\
\text { Partisipant, Process, dan } \\
\text { Physical Evidence) } \\
\text { terhadap } \\
\text { Keputusan Pembelian } \\
\text { Produk Klinik Kecantikan } \\
\text { Teta di Surabaya }\end{array}$ & $\begin{array}{l}\text { Dari ketujuh variable } \\
\text { : produk, harga, promosi, } \\
\text { lokasi, partisipant (beauty } \\
\text { therapist, dokter } \\
\text { dan receptionist), proses, d } \\
\text { an lingkungan fisik. } \\
\text { Variabel promosi adalah } \\
\text { variabel yang paling } \\
\text { dominan terhadap } \\
\text { keputusan pembelian pada } \\
\text { klinik kecantikan Teta di } \\
\text { kota Surabaya, }\end{array}$ & $\begin{array}{l}\text { Jurnal Mitra } \\
\text { Ekonomi dan } \\
\text { Manajemen Bisnis, } \\
\text { Vol.1, No. } 2: 216- \\
228\end{array}$ \\
\hline 5. & $\begin{array}{l}\text { Purwati } \\
\text { Heri Setiawan } \\
\text { Rohmawati } \\
(2012)\end{array}$ & $\begin{array}{l}\text { Pengaruh Harga Dan } \\
\text { Kualitas Produk Terhadap } \\
\text { Keputusan Pembelian } \\
\text { Motor Honda Matic Beat } \\
\text { (Studi Kasus Pada PT. } \\
\text { Nusantara Solar Sakti) }\end{array}$ & $\begin{array}{l}\text { Ketiga variabel } \\
\text { berpengaruh terhadap } \\
\text { keputusan pembelian Beat. } \\
\text { Kualitas produk } \\
\text { merupakan variabel paling } \\
\text { dominan }\end{array}$ & $\begin{array}{l}\text { Jurnal Ekonomi } \\
\text { Dan Informasi } \\
\text { Akuntansi } \\
\text { (JENIUS) Vol.2, } \\
\text { No.3 }\end{array}$ \\
\hline 6. & $\begin{array}{l}\text { Sarini Kodu } \\
\text { (2013) }\end{array}$ & $\begin{array}{l}\text { Harga, Kualitas Produk } \\
\text { Dan Kualitas Pelayanan } \\
\text { Pengaruhnya Terhadap } \\
\text { Keputusan Pembelian } \\
\text { Mobil Avanza }\end{array}$ & $\begin{array}{l}\text { Harga, kualitas produk dan } \\
\text { kualitas pelayanan } \\
\text { secara simultan maupun } \\
\text { parsial berpengaruh } \\
\text { signifikan terhadap } \\
\text { keputusan pembelian }\end{array}$ & $\begin{array}{l}\text { Jurnal EMBA } \\
\text { Vol.1, No.3 : } 1251 \text { - } \\
1259\end{array}$ \\
\hline
\end{tabular}




\section{Kerangka Konseptual}

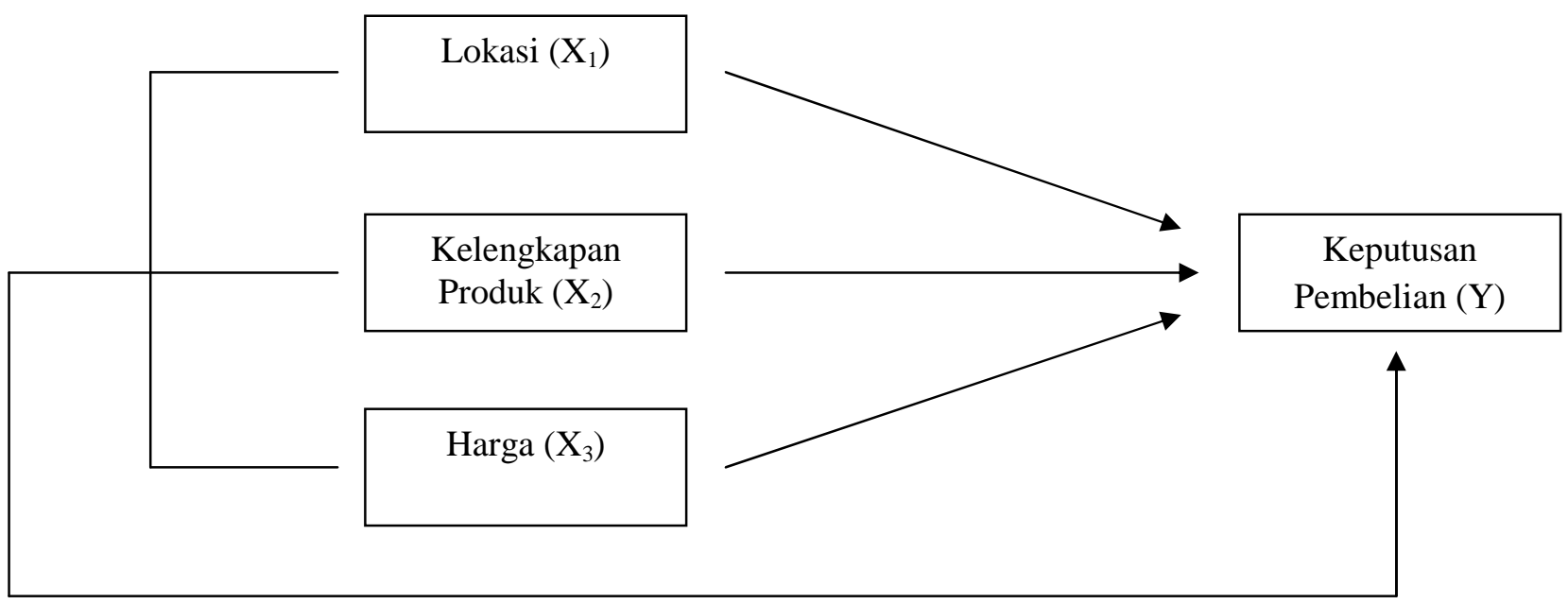

Gambar 2. Kerangka Konseptual

\section{Hipotesis}

1.Terdapat pengaruh lokasi terhadap keputusan pembelian konsumen Pajak USU (Pajus) Medan

2.Terdapat pengaruh kelengkapan produk terhadap keputusan pembelian konsumen Pajak USU (Pajus) Medan

3. Terdapat pengaruh harga terhadap keputusan pembelian konsumen Pajak USU (Pajus) Medan

4.Terdapat pengaruh lokasi, kelengkapan produk dan harga secara bersama-sama terhadap keputusan pembelian konsumen Pajak USU (Pajus) Medan

\section{METODOLOGI PENELITIAN \\ Lokasi Penelitian}

Penelitian ini dilakukan di Pajak USU (Pajus) Medan yang beralamat di Jalan Jamin Ginting Medan.

\section{Populasi dan Sampel \\ Populasi}

Populasi adalah wilayah generalisasi yang terdiri atas obyek/subyek yang mempunyai kualitas dan karekteristik tertentu yang di tetapkan oleh peneliti untuk dipelajari dan kemudian ditarik kesimpulannya (Sugiyono, 2008: 115).
Populasi dalam penelitian ini adalah seluruh konsumen yang pernah berbelanja di Pajak USU Medan.

Sampel

Sampel adalah sebagian dari jumlah dan karakteristik yang dimiliki oleh populasi (Sugiyono, 2001: 116). Teknik sampel yang digunakan yaitu non probability sampling yaitu teknik pengambilan sampel dengan tidak memberikan kesempatan yang sama bagi setiap unsur atau anggota populasi untuk menjadi sampel secara berulang. Sedangkan penentuan pengambilan responden dilakukan melalui teknik pengambilan sampel dengan pertimbangan tertentu yaitu responden yang memenuhi kriteria yang telah ditetapkan oleh peneliti (Sekaran, 2004: 140).

Penentuan jumlah minimal sampel menurut Rao Purba dalam (Ghazali,2010:89) dapat dihitung dengan rumus :

$$
\mathrm{n}=\frac{\mathrm{Z}^{2}}{4(M o e)^{2}}
$$

Dimana: $\quad \mathrm{n}=$ jumlah sampel $\mathrm{Z}=$ tingkat keyakinan yang dibutuhkan Moe $=$ margin of error 
Dengan tingkat keyakinan sebesar 95\% atau $\mathrm{Z}=1,96$ dan $\mathrm{Moe}=10 \%$ $(0,1)$ maka :

$$
\mathrm{n}=\frac{(1.96)^{2}}{4(0.1)^{2}}
$$

$\mathrm{n}=96,4$

Dari hasil perhitungan di atas maka jumlah sampel atau responden yang harus diteliti adalah 96,4 responden namun untuk memudahkan penelitian maka peneliti mengambil sampel sebesar 96 responden.

\section{Variabel Penelitian dan Defenisi Operasional Variabel Penelitian}

a. Variabel bebas dalam penelitian ini adalah :

1. Lokasi $\left(\mathrm{X}_{1}\right)$

2. Kelengkapan produk $\left(\mathrm{X}_{2}\right)$

3. Harga $\left(\mathrm{X}_{3}\right)$

b. Variabel terikat $(\mathrm{Y})=$

Keputusan Pembelian

\section{Defenisi Operasional Variabel}

1. Variabel bebas $(\mathrm{X})$

a. Lokasi $\left(\mathrm{X}_{1}\right)$

Lokasi adalah tempat secara fisik yang mempunyai fungsi strategis yang mudah dilihat dan dijangkau oleh konsumen sehingga dapat menentukan tercapainya tujuan badan usaha. Indikator : akses, visibilitas, lalu lintas, tempat parkir, ekspansi.

b. Kelengkapan Produk $\left(\mathrm{X}_{2}\right)$

Kelengkapan produk menyangkut kedalaman, luas dari kualitas produk yang ditawarkan juga ketersediaan produk tersebut setiap saat di toko. Indikator : kelengkapan jenis produk yang ditawarkan, kelengkapan produk merk yang ditawarkan, kelengkapan produk variasi ukuran yang ditawarkan, kelengkapan produk variasi kualitas produk yang ditawarkan.

c. Harga $\left(\mathrm{X}_{3}\right)$

Harga adalah jumlah uang yang ditukarkan konsumen dengan manfaat dari memiliki atau menggunakan produk dan jasa. Indikator : keterjangkauan harga, kesesuaian harga dengan kualitas produk, daya saing harga, kesesuaian harga dengan manfaat

2. Variabel terikat $(\mathrm{Y})$ : Keputusan

Pembelian

Keputusan pembelian (Y) adalah sebuah proses yang di lalui konsumen dalam mengenali masalah, mencari informasi, mengevaluasi alternatif, memilih salah satu di antara pilihan-pilihan yang telah mereka buat dan mengevaluasi tindakan keputusan pembelian. Indikator : kebutuhan yang dirasakan, kegiatan sebelum membeli, perilaku waktu memakai, perilaku pasca pembelian.

\section{Teknik Pengumpulan Data}

Teknik pengumpulan data yang di gunakan dalam penelitian ini adalah :

a. Observasi

Yaitu teknik pengumpulan data dengan cara mengamati secara langsung konsumen yyang menjadi objek penelitian. Pengamatan ini dilakukan secara langsung terhadap keadaan atau situasi Pajak USU (Pajus) dan mengkaitkannya dengan beberapa variabel yang diangkat dalam penelitian ini yaitu lokasi, kelengkapan produk dan harga.

b. Wawancara, yaitu melakukan pengumpulan data dengan cara tanya jawab dengan pedagang dan konsumen untuk mendapatkan data yang akurat.

c. Kuesioner yaitu dengan mengedarkan daftar pertanyaan yang berkaitan dengan lokasi, kelengkapan produk dan harga dalam keputusan konsumen membeli produk di Pajak USU (Pajus) Medan. Data dikumpulkan melalui teknik kuesioner yaitu berupa jawaban yang diberikan oleh responden.

\section{Teknik Analisis Data}

Teknik analisis data yang digunakan dalam penelitian ini adalah regresi berganda. Perhitungan analisis ini 
akan menggunakan program SPSS (Statistical Packages for the Social Science) versi 21.00

\section{HASIL PENELITIAN DAN \\ PEMBAHASAN \\ Hasil Penelitian}

Uji Validitas dan Reliabilitas Variabel Lokasi $\left(\mathbf{X}_{1}\right)$

Jumlah item pertanyaan variabel lokasi seluruhnya adalah 10 (sepuluh) butir dengan ketentuan apabila $\mathbf{r}_{\text {hitung }}>\mathbf{r}_{\text {tabel }}$ maka pernyataan valid tetapi jika $\mathbf{r}_{\text {hitung }}<$ $r_{\text {tabel }}$ maka pernyataan tidak valid, dimana nilai $r$ tabel pada taraf signifikan 0,05 adalah 0,361 (Tabel 1).

Tabel 1

Validitas Instrumen Lokasi

\begin{tabular}{|c|c|c|c|}
\hline $\begin{array}{c}\text { No. } \\
\text { Butir }\end{array}$ & $\mathbf{r}_{\text {hitung }}$ & $\mathbf{r}_{\text {tabel }}$ & Status \\
\hline 1. & 0,526 & 0,361 & Valid \\
\hline 2. & 0,387 & 0,361 & Valid \\
\hline 3. & 0,199 & 0,361 & Tidak Valid \\
\hline 4. & 0,100 & 0,361 & Tidak Valid \\
\hline 5. & 0,354 & 0,361 & Tidak Valid \\
\hline 6. & 0,116 & 0,361 & Tidak Valid \\
\hline 7. & 0,554 & 0,361 & Valid \\
\hline 8. & 0,616 & 0,361 & Valid \\
\hline 9. & 0,692 & 0,361 & Valid \\
\hline 10. & 0,368 & 0,361 & Valid \\
\hline
\end{tabular}

Hasil perhitungan reliabilitas dengan menggunakan uji Alpha Cronbach dinyatakan hasilnya sebesar 0,632 dan nilai ini lebih besar jika dibandingkan dengan nilai $r_{\text {tabel }}$ pada taraf signifikan 0,05 yaitu sebesar 0,361. Jadi dapat disimpulkan instrumen yang digunakan dalam angket penelitian ini adalah reliabel ( $\mathbf{r}_{\text {hitung }} 0,632$ $\left.>\mathrm{r}_{\text {tabel }} 0,361\right)$.

Tabel 2

\section{Hasil Perhitungan Reliabilitas} Angket Variabel Lokasi $\left(\mathbf{X}_{1}\right)$

Reliability Statistics

\begin{tabular}{|r|r|}
\hline Cronbach's Alpha & N of Items \\
\hline .632 & \\
\hline
\end{tabular}

Uji Validitas dan Reliabilitas Variabel Kelengkapan Produk $\left(\mathrm{X}_{2}\right)$

Jumlah item pertanyaan variabel kelengkapan produk seluruhnya adalah 8 (delapan) butir dengan ketentuan apabila $\mathrm{r}$ hitung $>r_{\text {tabel }}$ maka pernyataan valid tetapi jika $\mathbf{r}_{\text {hitung }}<\mathbf{r}_{\text {tabel }}$ maka pernyataan tidak valid, dimana nilai $r$ tabel pada taraf signifikan 0,05 adalah 0,361 (Tabel 1).

Tabel 3

Validitas Instrumen Kelengkapan Produk

\begin{tabular}{|c|c|c|c|}
\hline $\begin{array}{c}\text { No. } \\
\text { Butir }\end{array}$ & $\mathbf{r}_{\text {hitung }}$ & $\mathbf{r}_{\text {tabel }}$ & Status \\
\hline 1. & 0,632 & 0,361 & Valid \\
\hline 2. & 0,804 & 0,361 & Valid \\
\hline 3. & 0,715 & 0,361 & Valid \\
\hline 4. & 0,689 & 0,361 & Valid \\
\hline 5. & 0,531 & 0,361 & Valid \\
\hline 6. & 0,704 & 0,361 & Valid \\
\hline 7. & 0,562 & 0,361 & Valid \\
\hline 8. & 0,592 & 0,361 & Valid \\
\hline
\end{tabular}

Hasil perhitungan reliabilitas dengan menggunakan uji Alpha Cronbach dinyatakan hasilnya sebesar 0,815 dan nilai ini lebih besar jika dibandingkan dengan nilai $\mathbf{r}_{\text {tabel }}$ pada taraf signifikan 0,05 yaitu sebesar 0,361. Jadi dapat disimpulkan instrumen yang digunakan dalam angket penelitian ini adalah reliabel ( $\boldsymbol{r}_{\text {hitung }} 0,815$ $>\mathrm{r}_{\text {tabel }} 0,361$ ).

Tabel 4

Hasil Perhitungan Reliabilitas Angket Variabel Kelengkapan Produk $\left(\mathbf{X}_{2}\right)$

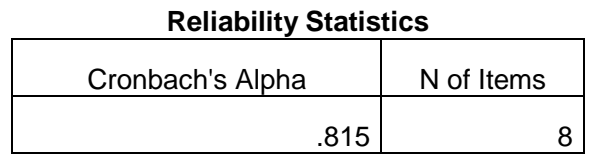

Uji Validitas dan Reliabilitas Variabel Harga $\left(\mathbf{X}_{3}\right)$

Jumlah item pertanyaan variabel harga seluruhnya adalah 7 (tujuh) butir dengan ketentuan apabila $\mathbf{r}_{\text {hitung }}>\mathrm{r}_{\text {tabel }}$ maka pernyataan valid tetapi jika $\mathbf{r}_{\text {hitung }}<$ $r$ tabel maka pernyataan tidak valid, dimana 
nilai $r$ tabel pada taraf signifikan 0,05 adalah 0,361 (Tabel 1).

Tabel 5

Validitas Instrumen Harga

\begin{tabular}{|c|c|c|c|}
\hline $\begin{array}{c}\text { No. } \\
\text { Butir }\end{array}$ & $\mathbf{r}_{\text {hitung }}$ & $\mathbf{r}_{\text {tabel }}$ & Status \\
\hline 1. & 0,757 & 0,361 & Valid \\
\hline 2. & 0,838 & 0,361 & Valid \\
\hline 3. & 0,463 & 0,361 & Valid \\
\hline 4. & 0,814 & 0,361 & Valid \\
\hline 5. & 0,852 & 0,361 & Valid \\
\hline 6. & 0,785 & 0,361 & Valid \\
\hline 7. & 0,724 & 0,361 & Valid \\
\hline
\end{tabular}

Hasil perhitungan reliabilitas dengan menggunakan uji Alpha Cronbach dinyatakan hasilnya sebesar 0,869 dan nilai ini lebih besar jika dibandingkan dengan nilai $r$ tabel pada taraf signifikan 0,05 yaitu sebesar 0,361. Jadi dapat disimpulkan instrumen yang digunakan dalam angket penelitian ini adalah reliabel ( $\mathbf{r}_{\text {hitung }} 0,869$ $\left.>\mathrm{r}_{\text {tabel }} 0,361\right)$.

Tabel 6

Hasil Perhitungan Reliabilitas Angket Variabel Harga $\left(\mathbf{X}_{3}\right)$

Reliability Statistics

\begin{tabular}{|r|r|}
\hline Cronbach's Alpha & N of Items \\
\hline .869 & 7 \\
\hline
\end{tabular}

Uji Validitas dan Reliabilitas Variabel Keputusan Pembelian (Y)

Jumlah item pertanyaan variabel keputusan pembelian seluruhnya adalah 8 (delapan) butir dengan ketentuan apabila $r$ hitung $>r$ tabel maka pernyataan valid tetapi jika $\mathbf{r}_{\text {hitung }}<\mathrm{r}_{\text {tabel }}$ maka pernyataan tidak valid, dimana nilai $\mathrm{r}$ tabel pada taraf signifikan 0,05 adalah 0,361 (Tabel 1).

Tabel 7

Validitas Instrumen Keputusan Pembelian

\begin{tabular}{|c|c|c|c|}
\hline $\begin{array}{c}\text { No. } \\
\text { Butir }\end{array}$ & $\mathbf{r}_{\text {hitung }}$ & $\mathbf{r}_{\text {tabel }}$ & Status \\
\hline 1. & 0,644 & 0,361 & Valid \\
\hline
\end{tabular}

\begin{tabular}{|c|c|c|c|}
\hline 2. & 0,612 & 0,361 & Valid \\
\hline 3. & 0,514 & 0,361 & Valid \\
\hline 4. & 0,547 & 0,361 & Valid \\
\hline 5. & 0,745 & 0,361 & Valid \\
\hline 6. & 0,849 & 0,361 & Valid \\
\hline 7. & 0,742 & 0,361 & Valid \\
\hline 8. & 0,743 & 0,361 & Valid \\
\hline
\end{tabular}

Hasil perhitungan reliabilitas dengan menggunakan uji Alpha Cronbach dinyatakan hasilnya sebesar 0,823 dan nilai ini lebih besar jika dibandingkan dengan nilai $\mathbf{r}_{\text {tabel }}$ pada taraf signifikan 0,05 yaitu sebesar 0,361. Jadi dapat disimpulkan instrumen yang digunakan dalam angket penelitian ini adalah reliabel ( $\mathbf{r}_{\text {hitung }} 0,823$

$\left.>\mathrm{r}_{\text {tabel }} 0,361\right)$.

Tabel 8

Hasil Perhitungan Reliabilitas Angket Variabel Keputusan Pembelian (Y)

Reliability Statistics

\begin{tabular}{|r|r|}
\hline Cronbach's Alpha & N of Items \\
\hline & .823 \\
\hline
\end{tabular}

\section{Analisis Regresi Berganda}

Model regresi berganda dengan satu variabel terikat (Y) yaitu keputusan pembelian dan tiga variabel bebas yaitu lokasi $\left(\mathrm{X}_{1}\right)$, kelengkapan produk $\left(\mathrm{X}_{2}\right)$ dan harga $\left(\mathrm{X}_{3}\right)$ adalah sebagai berikut :

$$
\mathbf{Y}=\mathbf{a}+\mathbf{b}_{1} \mathbf{X}_{1}+\mathbf{b}_{2} \mathbf{X}_{2}+\mathbf{b}_{3} \mathbf{X}_{3}+\mathbf{e}
$$

Tabel 9

\section{Koefisien Regresi}

\begin{tabular}{|c|c|c|c|c|c|c|c|c|}
\hline \multicolumn{9}{|c|}{ Coefficients $^{a}$} \\
\hline & \multirow[t]{2}{*}{ Model } & \multicolumn{2}{|c|}{$\begin{array}{c}\text { Unstandardiz } \\
\text { ed } \\
\text { Coefficients }\end{array}$} & \multirow{2}{*}{$\begin{array}{c}\begin{array}{c}\text { Standa } \\
\text { rdized } \\
\text { Coeffic } \\
\text { ients }\end{array} \\
\text { Beta }\end{array}$} & \multirow[t]{2}{*}{$\mathrm{t}$} & \multirow[t]{2}{*}{ Sig. } & \multicolumn{2}{|c|}{$\begin{array}{c}\text { Collinearity } \\
\text { Statistics }\end{array}$} \\
\hline & & B & $\begin{array}{l}\text { Std. } \\
\text { Error }\end{array}$ & & & & $\begin{array}{l}\text { Toler } \\
\text { ance }\end{array}$ & VIF \\
\hline \multirow{4}{*}{1} & (Constant) & .718 & .532 & & 1.351 & .180 & & \\
\hline & Lokasi & .050 & .117 & .039 & .432 & .667 & .914 & 1.094 \\
\hline & $\begin{array}{l}\text { Kelengkap } \\
\text { an Produk }\end{array}$ & .385 & .117 & .309 & 3.287 & .001 & .847 & 1.181 \\
\hline & Harga & .439 & .124 & .345 & 3.540 & .001 & .791 & 1.264 \\
\hline
\end{tabular}

a. Dependent Variable: Keputusan Pembelian 
Dari hasil pengolahan data, maka dapat dibuat persamaan regresinya sebagai berikut :

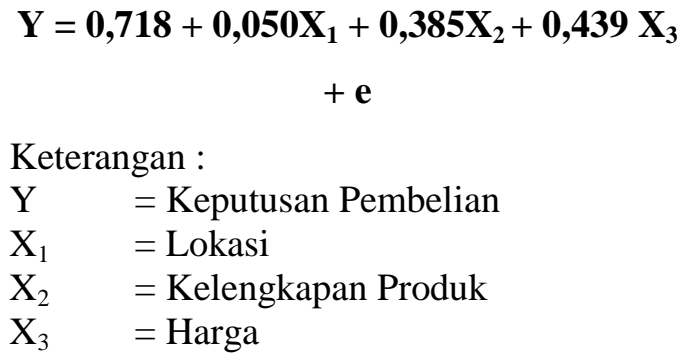

a. Konstanta sebesar 0,718 menyatakan bahwa jika tidak ada variabel $\mathrm{X}$ maka keputusan pembelian adalah 0,718 (asumsi faktor lain konstan).

b. Koefisien regresi $X_{1}$ sebesar 0,050 menyatakan bahwa setiap terjadi perubahan lokasi $1 \%$ akan mempengaruhi keputusan pembelian (asumsi faktor lain konstan).

c. Koefisien regresi $X_{2}$ sebesar 0,385 menyatakan bahwa setiap terjadi perubahan kelengkapan produk $1 \%$ akan mempengaruhi keputusan pembelian (asumsi faktor lain konstan).

d. Koefisien regresi $X_{3}$ sebesar 0,439 menyatakan bahwa setiap terjadi perubahan harga $1 \%$ akan mempengaruhi keputusan pembelian (asumsi faktor lain konstan).

\section{Uji Signifikansi Simultan (Uji F) \\ Tabel 10 Hasil Uji F}

\begin{tabular}{|r|l|r|r|r|r|r|}
\hline \multicolumn{2}{|c|}{ ANOVA $^{\text {a }}$} \\
\hline \multirow{2}{*}{ Model } & $\begin{array}{c}\text { Sum of } \\
\text { Squares }\end{array}$ & df & $\begin{array}{c}\text { Mean } \\
\text { Square }\end{array}$ & F & Sig. \\
\hline \multirow{2}{*}{1} & Regression & 9.619 & 3 & 3.206 & 13.804 & $.000^{\mathrm{b}}$ \\
\cline { 2 - 7 } & Residual & 21.370 & 92 & .232 & & \\
\cline { 2 - 7 } & Total & 30.990 & 95 & & & \\
\cline { 2 - 7 }
\end{tabular}

a. Dependent Variable: Keputusan Pembelian

b. Predictors: (Constant), Harga, Lokasi, Kelengkapan Produk

Berdasarkan tabel 4.23 angka $\mathrm{F}$ penelitian yang diperoleh dari hasil perhitungan adalah sebesar 13.804. Sedangkan angka $F_{\text {tabel }}$ dihitung dengan rumus $\mathrm{df} 1=\mathrm{k}-1 ; \mathrm{df} 2=\mathrm{n}-\mathrm{k}(3 ; 92)$ adalah
2,70. Dengan ketentuan tersebut diperoleh angka Ftabel $=2,70$.

Dengan demikian diperoleh nilai $F_{\text {hitung }}=13,804$, dan $F_{\text {tabel }}=2,70$. karena $\mathrm{F}_{\text {hitung }}>\mathrm{F}_{\text {tabel }}$ yang berarti bahwa $\mathrm{H}_{0}$ ditolak dan $\mathrm{Ha}$ diterima, sehingga dapat disimpulkan bahwa lokasi, kelengkapan produk dan harga berpengaruh positif dan signifikan terhadap keputusan pembelian.

\section{Uji Parsial (Uji t)}

\section{a. Pengujian Pengaruh X1 terhadap Y}

Secara individual uji statistik yang digunakan adalah uji t. Hasil perhitungan SPSS diperoleh angka $t_{\text {hitung }}$ sebesar 0,432. Untuk memperoleh besarnya $t_{\text {tabel }}$ dilakukan perhitungan sebagai berikut :

Taraf signifikansi 95\% dan alpha $5 \%$, serta derajat kebebasan (dk) dengan ketentuan $\mathrm{df}=\mathrm{n}-\mathrm{k}-1$ (pada penelitian ini $(\mathrm{df}=96-3-1=92)$. Dari ketentuan tersebut diperoleh angka $t_{\text {tabel }}$ sebesar $=1,661$. Kriteria uji hipotesis adalah sebagai berikut:

- Jika $t_{\text {hitung }}>\mathrm{t}_{\text {tabel }}, \mathrm{Ho}_{1}$ ditolak dan $\mathrm{Ha}_{1}$ diterima

- Jika $\mathrm{t}_{\text {hitung }}<\mathrm{t}_{\text {tabel }}$, maka $\mathrm{Ho}_{1}$ diterima dan $\mathrm{Ha}_{1}$ ditolak

Berdasarkan tabel Coefficients, diperoleh hasil 0,432 < 1,661, maka $\mathrm{Ho}_{1}$ diterima dan $\mathrm{Ha}_{1}$ ditolak. Hal ini berarti hipotesis ditolak yaitu lokasi tidak berpengaruh positif dan signifikan terhadap keputusan pembelian.

\section{b. Pengujian Pengaruh X2 terhadap Y}

Hasil perhitungan SPSS diperoleh angka $t_{\text {hitung }}$ sebesar 3,287. Untuk memperoleh besarnya $t_{\text {tabel }}$ dilakukan perhitungan sebagai berikut:

Taraf signifikansi $95 \%$ dan alpha 5\%, serta derajat keberbasan (dk) dengan ketentuan $\mathrm{df}=\mathrm{n}-\mathrm{k}-1$ pada penelitian ini $(\mathrm{df}=96-3-1=92)$. Dari ketentuan tersebut diperoleh angka $t_{\text {tabel }}$ sebesar $=1,661$. Kriteria uji hipotesis adalah sebagai berikut:

- Jika $t_{\text {hitung }}>\mathrm{t}_{\text {tabel}}, \mathrm{Ho}_{2}$ ditolak dan $\mathrm{Ha}_{2}$ diterima

- Jika $\mathrm{t}_{\text {hitung }}<\mathrm{t}_{\text {tabel}}$, maka $\mathrm{Ho}_{2}$ diterima dan $\mathrm{Ha}_{2}$ ditolak

Berdasarkan tabel Coefficients, diperoleh hasil 3,287 > 1,661, maka $\mathrm{Ho}_{2}$ ditolak dan $\mathrm{Ha}_{2}$ diterima. Hal ini berarti hipotesis diterima yaitu kelengkapan 
produk berpengaruh positif dan signifikan terhadap keputusan pembelian.

\section{c. Pengujian Pengaruh X3 terhadap Y}

Hasil perhitungan SPSS diperoleh angka $t_{\text {hitung }}$ sebesar 3,540. Untuk memperoleh besarnya $t_{\text {tabel }}$ dilakukan perhitungan sebagai berikut:

Taraf signifikansi $95 \%$ dan alpha $5 \%$, serta derajat keberbasan (dk) dengan ketentuan $\mathrm{df}=\mathrm{n}-\mathrm{k}-1$ pada penelitian ini (df=96-3-1=92). Dari ketentuan tersebut diperoleh angka $t_{\text {tabel }}$ sebesar $=1,661$. Kriteria uji hipotesis adalah sebagai berikut:

- Jika $t_{\text {hitung }}>\mathrm{t}_{\text {tabel }}, \mathrm{Ho}_{2}$ ditolak dan $\mathrm{Ha}_{2}$ diterima

- Jika $\mathrm{t}_{\text {hitung }}<\mathrm{t}_{\text {tabel}}$, maka $\mathrm{Ho}_{2}$ diterima dan $\mathrm{Ha}_{2}$ ditolak

Berdasarkan tabel Coefficients, diperoleh hasil 3,540 > 1,661, maka $\mathrm{Ho}_{2}$ ditolak dan $\mathrm{Ha}_{2}$ diterima. Hal ini berarti hipotesis diterima yaitu harga berpengaruh positif dan signifikan terhadap keputusan pembelian.

\section{Koefisien Determinasi}

\section{Tabel 11}

\section{Koefisien Determinasi}

\begin{tabular}{|l|r|r|r|c|}
\hline \multicolumn{1}{|c}{ Model Summary $^{\mathrm{b}}$} \\
\hline 1 & $\mathrm{R}$ & R Square & $\begin{array}{r}\text { Adjusted } \\
\text { R Square }\end{array}$ & $\begin{array}{c}\text { Std. Error } \\
\text { of the } \\
\text { Estimate }\end{array}$ \\
\hline 1 & $.557^{\mathrm{a}}$ & .310 & .288 & .48196 \\
\hline
\end{tabular}

a. Predictors: (Constant), Harga, Lokasi, Kelengkapan

Produk

b. Dependent Variable: Keputusan Pembelian

Berdasarkan tabel 11diperoleh $\mathrm{R}^{2}(0,310)<$ $\mathrm{R}(0,557)$, yang berarti syarat ini juga terpenuhi, sehingga dapat disimpulkan bahwa model penelitian ini terbebas dari multikolinearitas.

\section{SIMPULAN DAN SARAN Simpulan}

1. Berdasarkan perhitungan uji hipotesis secara parsial (Uji t) terhadap variabel lokasi, diperoleh $t_{\text {hitung }}>t_{\text {tabel }}$ dengan nilai $0,432<$
1,661. Hal ini berarti variabel lokasi tidak berpengaruh positif dan signifikan terhadap keputusan pembelian.

2. Berdasarkan perhitungan uji hipotesis secara parsial (Uji t) terhadap variabel kelengkapan produk, diperoleh $t_{\text {hitung }}>t_{\text {tabel }}$ dengan nilai 3,287 > 1,661. Hal ini berarti variabel kelengkapan produk berpengaruh positif dan signifikan terhadap keputusan pembelian.

3. Berdasarkan perhitungan uji hipotesis sacara parsial (Uji t) terhadap variabel harga, diperoleh $\mathrm{t}_{\text {hitung }}>\mathrm{t}_{\text {tabel }}$ dengan nilai 3,540 > 1,661 . Hal ini berarti variabel harga berpengaruh positif dan signifikan terhadap keputusan pembelian.

4. Dari hasil penelitian variabel lokasi, kelengkapan produk dan harga secara bersama-sama mempengaruhi keputusan pembelian pada Pajak USU (Pajus) Medan, hal ini dapat dilihat dari hasil perhitungan uji-F sebesar 13,804 dengan Ftabel 2,70 yang artinya Fhitung > Ftabel, menyatakan bahwa hipotesis diterima.

5. Di peroleh oleh nilai $\mathrm{R}$ square $\left(\mathrm{R}^{2}\right)$ $=0,310$ atau $31 \%$ yang artinya bahwa bahwa secara simultan lokasi, kelengkapan produk dan harga mempunyai pengaruh sebesar $31 \%$ terhadap keputusan pembelian dan $69 \%$ dipengaruhi oleh variabel lain diluar variabel yang diteliti.

\section{Saran}

1. Pengelola Pajak USU (Pajus) Medan sebaiknya lebih memperhatikan masalah lokasi seperti lahan parkir yang lebih luas dan keamanannya.

2. Pedagang di Pajak USU (Pajus) Medan sebaiknya lebih melengkapi variasi produk agar konsumen memiliki banyak pilihan dalam pembelian.

3. Pedagang di Pajak USU (Pajus) Medan tetap mempertahankan harga yang sesuai dengan manfaat 
yang diterima konsumen, kualitas dan kebutuhan konsumen.

4. Pengelola Pajak USU (Pajus) Medan sebaiknya melakukan penataan kios yang lebih baik agar memudahkan konsumen dalam melakukan pembelian.

5. Peneliti selanjutnya diharapkan mampu manambah faktor-faktor lain seperti variabel promosi, pelayanan, keamanan dan kenyamanan yang dapat mempengaruhi keputusan pembelian. Dengan demikian memberikan kontribusi yang baik untuk penelitian selanjutnya tentang keputusan pembelian.

\section{DAFTAR PUSTAKA}

Engel, dan Paul D Blaewel. 2002. Perilaku Konsumen Edisi Ke Enam. Binapura Aksara. Jakarta

Ghozali, Imam, 2010. Aplikasi Analisis Multivariate Dengan Program SPSS. Edisi Keempat, Penerbit Universitas Diponegoro.

Kotler, Philip, diterjemahkan oleh Hendra Teguh dan Ronny A. Rusli, 2002, Manajemen Pemasaran Edisi Millenium 1, PT. Prenhalindo, Jakarta.

2003. Manajemen Pemasaran. Edisi Kesebelas. Indeks Kelompok Gramedia. Jakarta

2005. Manajemen Pemasaran.

Edisi Kesebelas Jidil I dan II . Indeks. Jakarta

2008. Manajemen Pemasaran :Analisis, Perencanaan, Implementasi dan Pengendalian. Andi. Yogyakarta

2009. Manajemen Pemasaran. Erlangga. Jakarta
Kotler, Philip and Gary Amstrong. 2001. Prinsip-Prinsip Pemasaran, Jilid 2, Edisi ke-8. Erlangga. Jakarta

2004. Prinsip - Prinsip Pemasaran.. PT. Indeks Kelompok Gramedia. Jakarta

Prinsip-prinsip
Pemasaran,Jilid 1. Erlangga. Jakarta

Raharjani, Jeni. 2005. Analisis Faktor Faktor yang Mempengaruhi Keputusan Pemilihan Pasar Swalayan Sebagai Tempat Berbelanja (Studi Kasus Pada Pasar Swalayan di Kawasan Seputar Simpang Lima Semarang). Jurnal Studi Manajemen \& Organisasi, Vol. 2 No. 1 Hal 1-15.

Rahman, Diandaris Nurhandika. 2013. Pengaruh Kualitas Pelayanan, Fasilitas, Persepsi Harga Dan Lokasi Terhadap Kepuasan Konsumen Pada Pemancingan Ngembel Asri Gunung Pati Semarang. Fakultas Ekonomi Universitas Negeri Semarang. Skripsi.

Sahetapy, Jeofer Pratama. 2013. Diferensiasi Produk, Strategi Merek, Pengaruhnya Terhadap Keputusan Pembelian Meubel UD Sinar Sakti Manado. Jurnal Manajemen. Vol.1, No.3, Hal. 411-420.

Saladin, Djaslim. 2006. Manajemen Pemasaran. Lina Karya. Bandung

Schiffman \& Kanuk.2004. Perilaku Konsumen. Zulkifli Kasip (alih bahasa) Edisi Ketujuh. Penerbit PT. Indexs. Jakarta

Sekaran, Uma. 2004. Metodologi Penelitian Untuk Bisnis. Jilid 1. Edisi 4. Salemba Empat. Jakarta

Soewito, Yudhi. 2013. Kualitas Produk, Merek dan Desain Pengaruhnya Terhadap Keputusan Pembelian 
Sepeda Motor Yamaha Mio. Jurnal Ekonomi. Vol.1, No.3 Juni 2013.

Swastha, Basu. 2000, Azas-Azas Marketing, Edisi pertama, BPFE, Yogyakarta

Swastha, Basu dan Hani Handoko. 2011. Manajemen Pemasaran - Analisis Perilaku Konsumen. Edisi ke Enam. BPFE. Yogyakarta

Sugiyono. 2001. Metode Penelitian Administrasi. Penerbit Alfabeta. Bandung

2008. Metode Penelitian

Kunatitatif Kualitatif dan $R \& D$. Alfabeta. Bandung

Tandjung,J.W. 2004. Marketing Management:Pendekatan Pada Nilai-Nilai Pelanggan, Edisi Kedua,Cetakan Kedua. Bayu Media. Malang

Lupiyoadi, Rambat. 2001. Manajemen Pemasaran Jasa : Teori Dan Praktik. Edisi Pertama. Salemba Empat. Jakarta

Tjiptono, Fandy. 2008. Strategi Bisnis Pemasaran. Andi. Yogyakarta

Tjiptono, Fandy dan Gregorius Chandra. 2001. Service Quality And Satisfaction. Andi. Yogyakarta

Utami, Christian Whidya, 2006. Manajemen Riset Strategi dan Implementasi Riset Modern, Salemba Empat, Jakarta 